\title{
SEMANTIC SPACES OF INSTRUMENTAL AND ENSEMBLE PERFORMANCE: INVENTION-TENDENCY AT THE PRESENT STAGE
}

\section{Povzun L. I.}

\section{INTRODUCTION}

The slogan of instrumental and ensemble art of the XXXXI centuries, like the Baroque era, is invention, but now the requirements of ingenuity have touched the sphere of instrumental intonement: the composers reject the thesis of the obligatory desire for guasi vocal singing, and the ability of the instruments to imitate the instrumental sounds, natural or non-natural phenomena, comes to the fore. Again, the principle of "playing with masks" emerges - the principle of removal, going beyond the nature of the instrumental role, which is embodied in the use of unconventional methods of sounding on the instruments and leads to unexpected timbres.

Today, the dynamics of creative manifestations mostly characterizes the phenomenon of instrumental and ensemble performing sphere, since the genetic «core» and the generalizing indicator is the personal (artistic, psychological, technological) interaction of the performers as a unique form of artistic communication and reproduction, under the conditions of which psychical and sense development of the author's text is possible.

We pay attention to the artistic and performing aspects of instrumental and ensemble art that show the ability to transform many factors, that is, become mobile, making possible the sense multiplicity of reproduction of the composition artistic idea by the performers. Well, ambiguous are the space and acoustic conditions of performance (chamber, concert, plein air), and this involves the use of adapted to the aesthetically-spatial component of artistic and instrumental expressive means (delicately-chamber, overemotionally-concert). Thanks to the mobility of articulatory and dynamic ensemble indicators, authors' compositions gain genre and aesthetic universality. Instrumental and ensemble subspecies are distinguished by their quantitative and timbral characteristic, which determines their semantic functional and mis-en-scene distinctions; an additional element of mobility is caused by 
the ad libitum author's remarks of instruments quantitative / qualitative participation in the ensemble composition.

Semantic multiplicity of ensemble combinations, a wide range of tools of instrumental and artistic expression open new possibilities for creative experimentations of composers of different stylistic directions, to search for new «timbral mixtures», which use not only components established by historical performing practice, but also non-traditional timbral combinations of instruments (introduction of instrumental components of folklore or other nationality) that reproduce an alternative view of contemporary, in particular, Ukrainian authors on the artistic trends of the era - theatricality, mimesis, role bi-functionality, performing variety.

\section{Timbral and articulatory mimesis as a tool of instrumental and ensemble expression}

Each musical instrument in the ensemble is a living part of the artistic whole, which is capable of contributing to the creation of a particular musical image with the help of its abilities. The combination of instrumental components of the ensemble (acoustic, technological, articulatory, timbral, dynamic, etc.) in different possible variants gives different artistic results. Such variability leads to analogies with painting, where the process of mixing different colors will never give twice the same shade - even a slight deviation will inevitably lead to another artistic effect.

Each instrument has its own specific instrumental articulatory basis, which is unique only to it, unlike instrumental vocality, which is a part of all instruments and differs only in the means of achieving singing on the instrument. The «bar set» on the instruments of different timbral specifics composes the multifunctional system of instrumental and performing technologies as the basis of artistic and ensemble expressiveness.

In instrumental and ensemble compositions, the use of all timbral and articulatory possibilities in quite diverse, sometimes contrasting, combinations enriches the sound with new aggregate ensemble colors, and their masterful combination leads to the deepest disclosure of the author's content (see, for example, the piano party piano part in Sonata No.1 op. 120 by J. Brahms for alternative performance with clarinet or alto, where the ability of the pianist to find the string / wind specificity of 
sound presentation depends on the result of artistic integrity and stylistic authenticity of interpretation).

Differences of musical timbre are most often determined by descriptions, analogies with certain similarities, which play a significant role in the inheritance capabilities of instruments. The expressive capabilities of the various musical timbres are due to their organological qualities and the performing and technological means of playing them: timbre is determined by the nature of the sound production, which is specific to each instrument and the instrumentalist's performing tone, which is summarized in the concept of timbre and intonation (B. Asafiev's term); the latter indicates the emotional tone of the sound, its «nerve» and «degree», the degree of psychological and semantic saturation. The synergy of ensemble timbre and intonation produces a fundamentally new sound quality, which differs from individuallyindependent instrumental timbre, creating additional timbre-component sound-imaging effects.

It can be observed on the example of instrumental and ensemble compositions of the French romantic school composers: traditional organological combinations - bowed and stringed instruments and pianos allow to find an unusual aggregate-timbral color, which becomes a semantic center of the composition (the examples are the Piano Trio by E. Chausson, the Piano Quintet by S. Frank, Cello and Piano Sonata by C. Debussy).

The timbral qualities of a certain ensemble composition sometimes appear as a direct genre feature; for example, the emotional energy, festivity, and bright volume that are important when playing plein air are provided by brass instruments, as opposed to wooden-wind ones; the chamber softness and the intimacy of expression are capable of producing stringed trios, unlike piano trios.

In a solo composition, the modulation factor of timbral color is caused by changes in the register, loud dynamics, articulatory techniques, textures that contribute to the disclosure of different sides of the image, the growth of its expression. In the ensemble composition for several instruments, the timbral change becomes a significant aspect of artistic dramaturgy related to the development of «intonational plot» by changing the organological and timbral manifestation (timbre and intonation represent the personal quality of the image), which promotes the dialogization and polylogization of the ensemble texture, filling it with new semantic layers. 
The musical instrument in the ensemble composition is the bearer of a certain image-role, the artistic properties of which are manifested with the help of timbre - a spectrum of organologically-sound qualities that distinguish and identify it in the aggregate instrumental sound. Instrumental timbre, unlike pitch, duration, dynamic performance, cannot be ordered or characterized by a certain one-dimensional magnitude. The instrumental timbre-image cannot be ethically identified as a positive hero or an antihero (unlike a theater or opera character); specific characteristics of various musical timbre are most often determined by descriptions, analogies, which allow to give a musical and instrumental image to specific personality traits and to distinguish it due to characteristic features and associations (sensory, visual, audio).

Timbral and instrumental mimesis, as an organological ability to imitate, involves the reproduction of specific articulatory means of specific artistic and sound images, embodied in the author's idea of the composition:

- sound imitation of natural phenomena such as echo, wind noise, thunder, water play, waterfall;

- timbral imitation of the sound of other instruments, which presupposes the principle of expanding the articulatory-instrumental «vocabulary» by the involvement of other instrumental tools;

- intonational inheritance of certain national cultures, in particular, attraction of national articulatory and intonational indicators to create exotic sound color;

- style imitation - the artistic stylization of music by a certain author, using characteristic features of his style or musical «monograms».

The instrumental ability to mimesis does not imply the possibility of complete replacement of a specific instrument, but determines the quality-similarity to the conditional timbral meaning - a symbolic closeness to the sound associations with a particular instrument-image.

The study of the sound-inheriting potential of various instrumental groups gives the hypothesis that the volume of timbral mimetic possibilities determines the relevance and demand of a group of stringed and bowed and wooden wind instruments in the chamber and ensemble art sphere, and copper brass instruments are less able to "masking" their own organological qualities, so their use is limited to a specific sound role.

The organological paradigm of ensemble performance was formed over a long historical period, gradually collecting and refining instrumental examples that met the artistic and aesthetic demands of 
society and the spatial conditions of performance (chamber hall / concert hall / plein air). The decisive factor in the processes of selection and crystallization of the organological «core» of the instrumental and ensemble sphere were the artistic (articulatory, dynamic, timbral) properties of the instruments.

The value of the instrumental factor in the artistic and semantic concept of ensemble composition has increased significantly during the XX century: creative experiments of contemporary artists in search of new sounds have completely changed the traditional ideas about the soundness of instrumental compositions and the natural properties of instruments. Operation of sound, timbre, intonation as such, the composition with the "primary features» of the music material determines the creative search of contemporary authors, since music creativity and material are inevitably linked, musical creativity implies updating of resources that are not yet exhausted ${ }^{1}$.

The search for new multicolored sounds leads to the use of not only the natural artistic and technological qualities of instruments (with all the variety of ensemble assimilation of traditional methods of sound production), but also to the combination of musical and extra-musical sound effects: the latter go beyond the concept of instrumental sound production and become tools of the background layers - noise, phonism, tone (in particular, playing with the reel for timpani on the open strings of the piano in the piano quintet «Deo Volentum» by A. Tomlyonova), reveal a tendency to imitate the sound of not only certain instrumental timbres and natural phenomena, but also artificial phenomena (in the compositions of Tsepkolenko the combination of acoustic instruments and electronics experiments with analogical digital sound).

Due to fundamental changes in the general image of the modern world, the musical and aesthetic criteria have undergone significant changes, causing a rethinking of ideas about musical sound (sonority as a relevant type of modern composition technique), which opens a wide artistic space for the search of new soundings due to the immense scale of organological and articulatory, dynamically-agogic indicators. Experiments with any techniques of sound production, which is one of the characteristic features of sonoristics, are constantly updated with new

1 Булез П. Творчество, техника, язык // Homo musicus'99 : альманах музыкальной психологии. М. : МГК им. П. И. Чайковского, 1999. Сборник 25. C. 19-25. 
technological findings and greatly expand the possibilities of artistic, figurative and sound-imaging spheres of ensemble expression.

As E. Nazaykinsky points out, in the process of sound motion, noise and background elements are clearly distinguished, as well as the timbre of sound (somewhat perceived at the moment) and the timbre of the instrument (somewhat imaginary) in the aggregate. That means, the timbre manifests itself outside the category of formed pitch (height), volume, duration and spatial localization - it absorbs the effects of all other properties and acts as a characteristic of sound as a whole. "There is something interesting, useful and justifiable that the hearing takes from of the newest. The separation of sounds from their real sources is ensured by the multiplicity of instruments, voices, sound-producing objects and the fundamental diversification of their use. Here we are dealing with total timbre, similar to the noise of leaves, rain, waves, when many small vibrators, pathogens, resonators are mixed together. Therefore, unlike timbre and phonism, for which the spectral characteristics of the resonant body of the instrument and the vibrating body itself are important, with sonority, the noise activity of pathogens - bows, and with it the articulatory component of musical phonetics becomes more important"2.

Artistic tools of expression are associated with the distribution of sounds over time and with timbral color of sound presentation, which is formed by the combination of musical and non-musical means of expression (timbre, as the aggregate quality of sound, depends on many components: harmonic and non-harmonic partial tones, sound attack, vibration etc.). In the aggregate of sound components that are under the influence of the laws of the musical organization, the timbre, equally with other sound components, is «a source of structural radiation that permeates the musical texture and determines its specific character and shape» ${ }^{3}$.Investigating the spectral properties of the timbre, M. Garbuzov distinguishes the «objective» component of the timbre recorded by the spectrometer, and the «subjective» that occurs in our hearing aid as a result of the interaction of objectively existing audio overtones and all other partial tones. However, it is precisely from the partial tone ratio of

${ }^{2}$ Назайкинский Е. Музыка - звуковой мир: Тембр - фонизм - сонорность // Советская музыка. 1986. № 12. С. 80.

3 Бобровский В. Тематизм как фактор музыкального мышления. М. : Музыка, 1989. С. 22. 
the «objective» and «subjective» component that determines the timbre of the partial tone, and accordingly the timbre of the sound ${ }^{4}$.

According to Ukrainian researchers, the current era is an era of comprehensive detailing of the use of musical parameters and a radical modification of the musical language. Differentiation of means of musical expressiveness, achieving the functional independence of elements (parameters) due to their detailing leads to the formation of new principles of relations between them: if the classical phonematics of «European» musical language fit within the limits of the threedimensional coordinate system «height (pitch) - duration - dynamics» ${ }^{5}$, then a new intonational and sonoristic paradigm of contemporary music is represented as four-dimensional, with the addition of timbral and articulatory sound characteristics as an equal coordinate that becomes an independent paramount differential sign. Based on the above, V. Larchikov concludes that height (pitch), dynamics and duration are linear characteristics, while the new - fourth - differential feature has the properties not of coordinate as such, but of its own integral coordinate system. It appears as internal multidimensionality, the one that has a lot of parameters. It was the emancipation of the timbral and articulatory complex of parameters that led to the possibility of the infinite expansion of the "sound universe», which was observed in the second half of the $\mathrm{XX}$ century. The aesthetic sphere includes sounds and acoustic phenomena that were not previously related to music - a wide range of phenomena of noise genesis, sounds of nature and various manifestations of human activity («specific music»), etc. Humanity comes to the concept of infinity of timbral resources and sound capabilities of musical language ${ }^{6}$.

At the present stage, the discoveries of previous generations of artists in the field of instrumental expressive and aggregate timbral means are prolonged by identifying new articulatory possibilities in the intonation sphere, which, respectively, leads to the expansion of «articulatory performing vocabulary of the era» and to awareness of the infinite

\footnotetext{
${ }^{4}$ Гарбузов Н. А. Зонная природа тембрового слуха. М. : Государственное музыкальное издательство, 1956. С. 38

5 Шип С. Музыкальная речь и язык музыки. Одесса: ОГК им. А. В. Неждановой, 2001. С. 168.

6Ларчіков В. Музично-виконавський арсенал сучасного віолончеліста // Виконавське музикознавство : науковий вісник НМАУ імені П. І. Чайковського : збірка наукових праць. Київ, 2009. Вип. 82. С. 43.
} 
timbral potential in instrumental and ensemble combinations. And if in the previous historical stages the leading role in the creation of a certain «color» of the aggregate sound was played by the composition and the author's conception, today the leading role in the creation of the whole artistic composition belongs to the performers.

E. Nazaykinsky confirms our opinion: the emancipation of color is the result of isolation from the instruments of the vibrator with its independent «intonational behavior», the focus of attention towards illusory sources of sound. Here on a leading place there are «bows», subject of the musician's will - their articulatory drawing, whistling, whispering, muttering and other musical and phonetic effects. The concept of phonism is especially close to pianists, because the multiplicity of vibrators (strings and string choirs, rigidly fixed on the common resonator base of the piano and clearly separated from it) allows to achieve a tonal high-pitch uniqueness of sound against the background of timbral unity. Even more important is that with indirect timbral control using keyboard mechanics, the pianist can directly adjust the background effects of common polyphonic sound, using pedals and a thoughtful distribution of volume between individual components of the texture ${ }^{7}$.

The tendency for timbral inheritance mostly touched the piano, since the keyboard instrument - as an «orchestra substitute» - is genetically capable of timbral color. This ability in the newest stage of development of instrumental and ensemble creativity is used in its traditional «inclination» (imitation of the timbre of orchestral instruments), as well as in reproduction of the organological clavier row with all its predecessors and descendants. It is necessary to recall that the search for new sounds within the fixed piano timbre occurred in the compositions of composers of different instrumental schools - C. Debussy, M. Ravel, S. Frank, R. Strauss, E. Grieg, O. Skryabin, O. Messian, marked by a tendency to compare the clavier timbre of pedal sounds with the sounds of guasi organ, guasi cembalo, guasi harpsichord, guasi electro-piano, guasi electro-organ, which opposes the orchestral and clavier specificity of the embodiment. The characteristic integrity of multi-sounding, which has always determined the essence of the clavier, in the specifics of ensemble embodiment breaks down into the multiplicity of historically

${ }^{7}$ Назайкинский Е. Музыка - звуковой мир: Тембр - фонизм - сонорность // Советская музыка. 1986. № 12. С. 83. 
tested timbral techniques and carries out timbral «transformation» within the framework of fixed mechanics. To this there can be added an indication of the new timbral colors actively used by composers in ensemble music at the present stage: guasi harp, guasi electric guitar, guasi contrabass, guasi bandura, guasi percussion instruments.

The list of "timbral resources" of the keyboard does not exclude attention to basic classical and romantic settings: the cantilena and the desire to bring the instrumental sound closer to the vocal cantabile certainly remains the standard of sound not only for the piano, but also for all instruments and as a sound culture determines the level of professional skill of the performers.

In the modern culture of piano sound traditional articulatory techniques have undergone a significant transformation - the use of the instrument's percussion capabilities, playing the open strings of the piano, percussion on the instrument cover (sometimes with the open right pedal), «prepared» piano (with the use of auxiliary objects), emphasized piano resonance, a special commitment to imitation of percussion, stringed and plucked (folk and ancient) instruments, widespread use of clusters, curl effects, etc.

The processes of expansion and diversification of the timbral and instrumental potential of the aggregate ensemble sound field confirm the general historical tendency of constant updating of technological and artistic expressive sphere of ensemble performance.

\section{Instrumental theatre in the modern Ukrainian dimension}

The semantic multi-vector of instrumental and ensemble genres, the wide range of articulatory and timbral, dynamically-agogic means of joint expression make this sphere especially attractive for the creative search of composers of almost every artistic direction. The increased attention to instrumental and ensemble performance is confirmed by the considerable number of works of contemporary Ukrainian composers, for whom instrumental and ensemble genres have become a priority area of artistic creativity, since they have been able to actualize a number of the major international trends in world music culture.

According to L. Kyyanovska, intensive search for innovative means of expression allow the chamber and instrumental music to remain invariably a sphere of intense intellectual work in mastering the musical 
and dialogical form of «higher psychological complexity» ${ }^{8}$. According to Pavlyshyn, in the second half of the XX century the concept of «chamber ensemble» disappears, and instead the program concept of «instrumental theater» emerges, which, in addition to the music itself and a certain plot generalization, includes the actor's actions of performers. Instrumental theater has many individual variants"9.

The tendency for theatricalization of instrumental and performing arts has become a reproduction of the contemporary artistic integrative approach, characterized by the vision of intertextual identities in the diversity of genres and style traditions. Musical and instrumental theater on the verge of the XX and XXI centuries is a striking example of such tendencies, and at the same time it is an appeal to the primary models of musical, in particular, instrumental and ensemble creativity, which was a part of syncretic action (combination of music, words, dance, and theatrical action). However, speaking of a certain synthesis of the arts, we are aware of a new level of artistic phenomena fusion, resulting in not just mutual genre assimilation, but the emergence of a new expressive form of performance. And, as E. Bondar points out, an art work must be a «revelation», it must surprise, give the listener, the viewer a new image, powerful, intense by the force of emotion. Artistic means of contemporary performance (intonational and artistic, motor, visual, etc.) have their own volume of semantic and expressive possibilities, «conditioned both by the objective properties and vital connections of this means, as well as by the ability of this means, developed in the course of the musical historical process, to cause certain ideas and associations" $"$.

8 Кияновська Л. Специфіка камерно-інструментального мислення Мирослава Скорика (на прикладі творчості останнього двадцятиріччя) // Камерно-інструментальний ансамбль: Історія, теорія, практика: Виконавське мистецтво: наукові збірки ЛНМА імені М. В. Лисенка. Львів : Сполом, 2011. Вип. 25. С. $7 .$.

${ }^{9}$ Павлишин С. Еволюція камерного ансамблю // Камерно-інструментальний ансамбль: Історія, теорія, практика: Виконавське мистецтво: наукові збірки ЛНМА імені М. В. Лисенка. Львів : Сполом, 2015. Випуск 34. С. 17.

${ }^{10}$ Бондарь Е. Современное хоровое исполнительство : новый синкретизм или синтез искусств // Музичне мистецтво і культура : науковий вісник : збірка наукових праць ОНМА ім. А. В. Нежданової.. Одеса : Астропринт, 2012. Вип. 15. С. 341. 
The use of the term «theatricalization» implies a set of specific means and techniques inherent in theatrical art. We consider theatricals in the instrumentalists' creative work as:

- performance and play of a certain role in a musical composition;

- performance and play in a certain «instrumental mask» (a play in a play);

- a certain manner (method, reception) of artistic and instrumental embodiment;

- active use of additional theatrical means (facial expressions, gestures, stage action);

- conscious underlining of the means of stage expression (overemotionality, over-dynamics of instrumental expression);

- reinforcement of the program-plot aspect of the composer's plan, which implies a certain model of musical and dramatic «action".

According to A. Samoilenko, theatricality is an important aspect of the instrumental and performing play, which the author defines as a multifunctional epiphenomenon of musical semantics, which simultaneously addresses the cultural, artistic and compositional, textual, stylistic and psychological conditions of musical creativity ${ }^{11}$.

Of course, mostly thearicalization in the presentation of musical material is used by performers in the concert and stage genres, but chamber and ensemble work has historically found its place on the concert stage. And at the present stage in the instrumental and ensemble performance through the interaction of several genres (instrumental, music and word, dance, video, stage), a number of theatrical features are reproduced: special organization and sense of artistic space and time, increased share of the play and gesturing, the presence of conductor and actor's actions from the side of musicians-instrumentalists.

Different aspects of the embodiment of theatricality in instrumental music are manifested in the specifics of the choice of imagery, dramaturgy, and composition, directing and performing factors, since in the performance action there is a combination of two worlds conditionally compositional and realistically performing. Formation of a complete composition of the ensemble work involves simultanic instrumental dramaturgy, which, according to A. Nivelt, is a type of

11 Самойленко А. Музыкознание как «живая история» культуры: К проблеме диалогичности гуманитарного знания // Трансформація музичної освіти: культура та сучасність: матеріали музикологічного семінару. Одеса : Астропринт, 1998. Ч. 1. С. 91-102. 
dramaturgy of the highest order and is based on the interaction of two or more dramatic development lines, including multifaceted genre base, temporal and spatial indicators of musical and stage composition ${ }^{12}$.

The opera director O. Shchoholiv, studying the origins of performance and theatrical action, came to the conclusion that actorsmusicians are able to make music by acting, because they not only hear music, but also «see» it ${ }^{13}$. Y. Vysotsky has a similar opinion, arguing that the perception of music is not only a matter of hearing but also of sight, so it requires an organic combination of the performing arts with theatrical $^{14}$.

Theatricalization of the instrumental and ensemble performing space implies a certain spatial transformation, as the listener becomes a listenerspectator. And this requires the extension of the boundaries of the established listening space. However, it should be noted that auditory and visual connections in music have a long tradition: seven musical sounds of the Middle Ages indicated seven main colors - red, orange, yellow, green, blue, indigo and purple. In the XVII century, voices in scores were designated with certain colors: soprano - red, alto - yellow, tenor - green, bass - blue. Color associations also relate to tonal perception, in particular, known, but not well-researched, facts of color hearing (synopsis), which was characteristic of M. Rimsky-Korsakov, O. Skryabin, B. Asafiev, O. Messian. S. Lyudkevich, who had his own mind on the beauty of individual sounds and the laws of their combinations («musical art operates with tones and their combinations»), called the phenomenon of the interaction of music and colors «a sense of tonation» ${ }^{15}$.

Characteristic of contemporary composers, the sensitivity to the musical space is manifested in particular attention to the acoustic environment in which the performance takes place; sometimes it is the

12 Нивельт О. Симультанный тип оперной драматургии // Музичне мистецтво i культура: науковий вісник ОДМА імені А. В. Неждановой . Одеса : Друкарський дім, 2006. Кн. 1, вип. 7. С. 16.

13 Щоголів В. Музичний театр «Зона мовчання»- дослідження джерела // Виконавське музикознавство : науковий вісник НМАУ імені П. І. Чайковського.. Київ, 2009. Випуск 82. С. 268.

14 Высоцкий Ю. Мистерии театра скрипки // Зеркало недели. 2000. № 16 (289). С. 20.

15 Людкевич С. Про красу звуку : Дослідження, статті, рецензії, виступи // Історія української музики / [упор., ред., перекл., вст. ст. З. Штундера] ; Інститут українознавства ім. I. Крип'якевича. Львів : Видавництво М. Коць, 1999. Т. 1. Вип. 5. С. 205. 
use of room acoustics to create a multidimensional sound associated with a particular location of the performers (on and off the stage, at different corners of the hall, the movement of musicians around the listeners, the combination of real sound with electronic recording).

Substantial changes are taking place in the sphere of the musical performing and listening space, presented in the works of contemporary authors in quite a diverse way:

- changing the «listening position» with the transition from close-up to general (and vice versa) is perceived as a rapid jump in sound quality (for example, from tutti ffff to ppp of flutes and violins); wide air space of multi-octal duplication with gradual filling with various rhythmic variants; during a gradual change in dynamics the effect of zooming in or out is created;

- one of the characteristic features of contemporary music sound is the multiplicity and sophistication of «long-range plans»: the comparison of background and relief, close and distant plans (the latter are often quiet in sound and slow in motion or very still), contrasting use of «close-up» (maximum loud with characteristic instructions «marcatissimo», «furioso»);

- typical is the relationship aggravation of «dense» and «transparent» texture, hence the violation of the continuity of sound volume, «torn» texture (super-dense texture is formed with the help of saturated chords, sometimes with melodic «germination» of individual voices, clusters);

- one of the means of reproducing dramatic tension is filling the entire space with contrasting thematic layers that unfold independently, forming a multidimensional space - as a «space of action».

According to N. Gerasimova-Persidskaya, in complex-organized spaces there appears an opportunity for not one musical phenomenon to acquire a volume, but for many phenomena to interact in different ways, forming a complex system of sound volumes correlation ${ }^{16}$.

An example of the artistic interaction of volumetric and dimensional, sonorously-dynamic and spatial contrasts in the ensemble texture is A. Tomlyonova's composition «Whispers and Cries», which reproduces the expression of human being and the polar points of its sound

${ }^{16}$ Герасимова-Персидская Н. Выход к новым принципам пространственновременной организации музыки в переломные эпохи // Музыкальное мышление: сущность, категории, аспекты исследования : сборник статей. Київ : Музична Україна, 1989. С. 61, 62. 
manifestation (a composition written on the basis of the Swedish film directed by Bergman).

Using the chronotopic interaction of historical and temporal, dynamical and timbral indices, Y. Gomelskaya in the composition "The Wings of the Eastern Wind" (for flute, clarinet, violin, cello and piano) unveils her own vision of Eastern culture, without resorting to a specific national and intonational color, unlike the duet «Rising. East - West» for piano and percussion, in which the ensemble combination shows intonational and sound juxtaposition of cultures. The author achieves stylization, not through quotations, but through the use of unconventional techniques or the use of auxiliaries (similar to the piano improvisation and percussion on the open strings of the piano imitate the sound of a multi-stringed Indian instrument).

According to G. Zavgorodnya, the bright personality of Y. Gomelskaya's is directly connected with the extreme authorization of musical style and genre searches, which leads to the personalization (separation) and special independence of the leading regularities of the structure of such a phenomenon as musical language. The fundamental principle of organizing sound material is the composer's installation of various combinatorics associated with the primary elements of the musical language as a structural unit that «encodes» in itself both the content and the overall compositional potential ${ }^{17}$.

Turning back to instrumental and ensemble creativity, first of all, Y. Gomelskaya develops a scenario of instrumental relationships, as the titles of the compositions eloquently attest: «Trap for Two» for soprano saxophone and alto saxophone; «... Herbarium... music of memories...» for violin, alto and cello; "Carl and Clara" for clarinet and piano, "Synopsis of Symmetries" for flute, alto and cello; «From the bottom of the soul» for string quartet; «Forgotten Ritual» for flute, alto saxophone, piano and percussion; «Through the Gothic Mosaic Crystals» for flute / alto flute, cello and piano, etc.

The storyline unfolds in rather unexpected dialogues of instrumental timbres, and the author pays special attention to the spatial properties of the ensemble texture, forming a specific timbral density of sound space, while separating each timbre personality of the musical action. For

17 Завгородняя Г. Полифонические аспекты организации музыкального пространства в творчестве Ю. Гомельской // Музичне мистецтво і культура. Науковий вісник ОДМА імені А. В. Нежданової: збірка наукових праць. Одеса : Друкарський дім, 2010. Вип. 11. С. 312. 
example, in the duet «Dia Dem» violin and cello monologues exhibit boundary poles - the contrast of two principles in nature, in which, according to G. Zavgorodnya, the opposite of divine and devilish, male and female, incompatible bases of thinking of different types of personality is determined ${ }^{18}$.

Interesting is the instrumental and timbral view of Y. Gomelskaya on the archaic layers of pagan Slavic rites in the composition «To the sun. Spring Ritual»: the author created two versions of the composition, the first of which was a two-piano, the second - a piano quintet for the traditional composition (reminiscent of the history of the organological transformation of J. Brahms Piano Quintet, op. 34).

Manifestations of role bi-functionality are observed in the use of the verbal series (singing, declamation of the text) in the ensemble texture of the instrumental composition, when the performing musical instrument is overlaid with the spoken instrumental replicas. This allows to achieve not only the necessary emotional but also plot development: for example, in the Gomelskaya's "Fonium-Folk" Quartet, the voices of instrumentalists forming a kind of verbal polyphony are gradually added for dynamic growth and textural compaction.

A similar enrichment and «additional» timbral saturation of the ensemble texture, without increasing the number of instrumental participants, is reached by A. Tomlyonova in Sonata for alto and piano, which provides simultaneous or alternate holding of several instrumental parts by one performer (in particular, in the finale, the piano party switches to bell sounds); in the Piano Trio by K. Tsepkolenko «Doors wide open» the pianist plays percussion instruments. Such «universal instrumentalism» is a historical dialogue with the Baroque era, when the standard of the perfect ensemble was the ability to master all the instruments of composition (J. Matheson's tractate «The Perfect Kapellmeister»).

All of the above-mentioned confirms the importance of the performing factor in the process of embodiment of the author's idea and allows us to consider the leading aspect of the instrumental and ensemble creativity of the modern period, since it is the conceptual-emotional

18 Завгородняя Г. Полифонические аспекты организации музыкального пространства в творчестве Ю. Гомельской // Музичне мистецтво і культура. Науковий вісник ОДМА імені А. В. Нежданової : збірка наукових праць. Одеса : Друкарський дім, 2010. Вип. 11. С. 319. 
integrity of the artistic realization and the musical integrity of the instrumentality that depends largely on the artistry and mastering.

Thus, instrumental theatricalization is an important aspect of ensemble performance, which simultaneously addresses the cultural, artistic, compositional, textual, stylistic, and psychological conditions of musical creativity.

\section{CONCLUSIONS}

The processes of expansion of the ensemble «artistic and sound field», which at the present stage happen through the introduction of non-academic instruments, new techniques and means of sound production on the instruments of the classical sample, attracting «noise» objects to diversify the aggregate sound, at the beginning of XXI century, confirm the historical tendency of constant updating of technological and artistic expressive sphere of ensemble performance.

The transformation of ideas that occur in the interpretation of traditional musical instruments, active experimentation with them causes a significant expansion of the palette of their expressive means, the introduction of unknown before and often significantly different from the «classical» performing techniques, means of sound production, articulation. And this requires the systematization of their application and the creation of a special reference and theoretical base with generalization of new information on the means of sound production.

All modern inventions in the instrumental and articulatory sphere are aimed at reproduction of certain timbral and sound qualities that can cause symbolic figurative and semantic associations. And therefore, the volume of timbral mimetic abilities determines the relevance of certain instruments participation in the musical-plot action.

An analysis of the mimetic ability of instruments with different peculiarities of musical «breathing» to imitate sound complexes (natural, other instrumental, extra-natural) revealed the advantage of stringed bowed instruments over stringed plucked and wind instruments in the number of «sound roles», which is largely due to the organological paradigm of ensemble performance.

The modern instrumental timbral mimetic trend has greatly expanded the traditional «imitation zone» of the piano, which is used both in its traditional «inclination» - guasi orchestral instruments, and for playing the clavier in a variety of predecessors and descendants (guasi organ, guasi cembalo, guasi harpsichord, guasi electro-piano, etc.) to which new timbral colors of other instrumental sphere (guasi harp, guasi electric 
guitar, guasi contrabass / bass, guasi bandura, guasi percussion instruments) are added.

On the verge of the XX-XXI centuries the concept of chamber ensemble begins to include the concept of instrumental theater in its subject content; the latter receives a plurality of individual-author manifestations, the purely sound realization of the author's composition is complemented with the plot-acting and bi-instrumental actions of the performers, which increases the importance of the performing factor in the process of embodying the artistic concept, and extends genre communication to the concept "performer - listener/spectator".

\section{SUMMARY}

Instrumental and ensemble performing sphere becomes an area of creative experimentations of contemporary authors, a sphere of search for new timbral and ensemble combinations, which use not only components established by historical performing practice, but also nontraditional timbral combinations of instruments that reproduce the alternative view of Ukrainian artists on artistic aspects.

At the present stage, the discoveries of previous generations of artists in the field of instrumental expressive and aggregate timbral means are getting their prolongation by identifying new articulatory possibilities in the intonational sphere, which leads to the expansion of «articulatoryperforming vocabulary of the era» and to the conscious awareness of instrumental and ensemble connections.

Timbral mimetic inventions in the instrumental and articulatory sphere are aimed at reproduction of certain sound qualities that cause symbolic figurative and semantic associations (sensory, visual, audio). The mimetic ability of the instrumental series significantly expands the artistic spectrum of the sound capabilities of ensemble performance. If in the previous historical stages the leading role in the creation of a certain «color» of the aggregate sound was played by the composition and the author's conception, at the present stage the leading role in the creation of the artistic whole composition belongs to the performers.

Introducing the techniques of theatricalization into the ensemble compositions of contemporary authors brings to the subject circle the concept of instrumental theater - musical and instrumental program plots-performances with a planned script action. This increases the importance of the performing factor in the process of artistic conception embodiment and makes possible the musical and video integrity. 


\section{REFERENCES}

1. Бобровский В. Тематизм как фактор музыкального мышления. М. : Музыка, 1989. С. 22.

2. Бондарь Е. Современное хоровое исполнительство : новый синкретизм или синтез искусств // Музичне мистецтво і культура : науковий вісник: збірка наукових праць ОНМА ім. А. В. Нежданової . Одеса : Астропринт, 2012. Вип. 15. С. 339-349.

3. Булез П. Творчество, техника, язык // Homo musicus'99 : альманах музыкальной психологии. М. : МГК им. П. И. Чайковского, 1999. Сборник 25. С. 19-25.

4. Высоцкий Ю. Мистерии театра скрипки // Зеркало недели. 2000. № 16 (289). С. 19-21.

5. Гарбузов Н. А. Зонная природа тембрового слуха. М. : Государственное музыкальное издательство, 1956. С. 38.

6. Герасимова-Персидская Н. Выход к новым принципам пространственно-временной организации музыки в переломные эпохи //Музыкальное мышление: сущность, категории, аспекты исследования : сборник статей. Київ : Музична Україна, 1989. С. 54-64.

7. Завгородняя Г. Полифонические аспекты организации музыкального пространства в творчестве Ю. Гомельской // Музичне мистецтво i культура. Науковий вісник ОДМА імені А. В. Нежданової : збірка наукових праць. Одеса : Друкарський дім, 2010. Вип. 11. С. 312-321.

8. Кияновська Л. Специфіка камерно-інструментального мислення Мирослава Скорика (на прикладі творчості останнього двадцятиріччя) // Камерно-інструментальний ансамбль: Історія, теорія, практика: Виконавське мистецтво: наукові збірки ЛНМА імені М. В. Лисенка. Львів : Сполом, 2011. Вип. 25. С. 7-16.

9. Ларчіков В. Музично-виконавський арсенал сучасного віолончеліста // Виконавське музикознавство: науковий вісник НМАУ імені П. І. Чайковського : збірка наукових праць. Київ, 2009. Вип. 82. С. 43-61.

10. Людкевич С. Про красу звуку : Дослідження, статті, рецензії, виступи // Історія української музики; Інститут українознавства ім. І. Крип’якевича. Львів : Видавництво М. Коць, 1999. Т. 1. Вип. 5. $495 \mathrm{c}$.

11.Назайкинский Е. Музыка - звуковой мир: Тембр - фонизм сонорность // Советская музыка. 1986. № 12. С. 75-82. 
12.Нивельт О. Симультанный тип оперной драматургии // Музичне мистецтво і культура: науковий вісник ОДМА імені А. В. Неждановой. Одеса : Друкарський дім, 2006. Кн. 1, вип. 7. C. $16-25$.

13.Павлишин С. Еволюція камерного ансамблю // // Камерноінструментальний ансамбль: Історія, теорія, практика: Виконавське мистецтво: наукові збірки ЛНМА імені М. В. Лисенка. Львів : Сполом, 2015. Випуск 34. С. 16-21.

14.Самойленко А. Музыкознание как «живая история» культуры: К проблеме диалогичности гуманитарного знания // Трансформація музичної освіти: культура та сучасність: матеріали музикологічного семінару. Одеса : Астропринт, 1998. Ч. 1. C. 91-102.

15.Шип С. Музыкальная речь и язык музыки. Одесса: ОГК им. А. В. Неждановой, 2001. 296 с.

16. Щоголів В. Музичний театр «Зона мовчання» - дослідження джерела // Виконавське музикознавство : науковий вісник НМАУ імені П. І. Чайковського. Київ, 2009. Випуск 82. С. 263-275.

\section{Information about the author:}

Povzun L. I.,

Doctor of Art Studies, Professor of the Department of Chamber Ensemble, Head of the Department of Chamber Ensemble, Odessa National A. V. Nezhdanova Academy of Music 63, Novoselskogo str., Odessa, 65023, Ukraine 